\title{
The Effect of Concept Circle Strategy on Students' Vocabulary Mastery at Grade VII MTs N 2 Padangsidimpuan
}

\author{
By: Dr. Fitriadi Lubis, M.Pd., Sojuangon Rambe, S.S., M.Hum., \\ and Rahmi Pu'adi Siregar
}

\begin{abstract}
ABSTRAK
Penelitian ini difokuskan pada pengaruh Strategi Lingkaran Konsep pada penguasaan kosakata siswa pada kelas VII MTs N 2 Padangsidimpuan. Metode yang digunakan dalam penelitian ini adalah penelitian eksperimental. Dua kelas dipilih secara acak sebagai sampel. Mereka adalah kelas VII-2 sebagai kelas eksperimen yang terdiri dari 24 siswa dan kelas VII-3 sebagai kelas kontrol yang terdiri dari 22 siswa. Itu diambil setelah melakukan uji normalitas dan homogenitas. Data tersebut berasal dari pre-test dan post-test. Untuk menganalisa data, peneliti menggunakan rumus t-test. Setelah menganalisis data, peneliti menemukan bahwa rata-rata skor kelas eksperimen setelah menggunakan Strategi Lingkaran Konsep lebih tinggi daripada kelas kontrol. Skor ratarata kelas eksperimen sebelum menggunakan strategi Concept Circle adalah 55,62 dan skor rata-rata setelah menggunakan strategi Concept Circle adalah 82,62. Sedangkan skor rata-rata kelas kontrol pada post test adalah 68,58. Selain itu, nilai t hitung lebih besar dari ttabel (4.205> 2.021). Artinya hipotesis alternatif (Ha) diterima. Disimpulkan bahwa ada pengaruh yang signifikan dari strategi Concept Circle pada Penguasaan Kosakata Siswa pada kelas VII MTs N 2 Padangsidimpuan.
\end{abstract}

\section{Keyword: Strategi Concpet Circle dan Penguasaan Kosakata}

\section{A. INTRODUCTION}

To master English of students will not be good. There are some reasons why students need to learn and why students need to mastery of vocabulary. The first, vocabulary will help the students to comprehend the information from those sources such as magazine, novel, newspaper, and internet if they have many vocabularies. Second, vocabularies help the students to know what people says. Third, vocabularies will help them to share their ideas. The last, vocabularies help the students active to communicate if they has well vocabularies.

Based on the information from Dewi as English teacher in MTs N 2 Padangsidimpuan the students in this Junior High School are low in vocabulary. It makes them bad in understanding or comprehending English spoken and difficult to speak in good English. They are also bad in understanding English passage and difficult to write their thought in written form. The students have some problems in 
vocabulary mastery, such as bad pronunciation, difficult to understand new words, and the worst problem is that students do not know many words. The problems are caused by several reasons such as students' educational background, their less practice, interesting and motivation, their bad mindset about English, their less strategy to learn vocabulary and the teacher's less strategies in teaching. ${ }^{1}$ The researcher thinks that it is a big problem.

There are many strategies that can be applied in teaching vocabulary. Some of the popular strategies are List-Label-Group, Dictoglos, Frayer Model, Word Sorts and Concept Circle Strategy and other. Those various strategies are suitable and good for enjoyable teaching and learning process in vocabulary classes.

One of the strategies to teach vocabulary is Concept Circle strategy. This vocabulary teaching strategy uses some Circle and divided four section. Describe the Topic and answer based on characteristics or definition in the Concept Circle straegy. So, Concept Circle strategy used to describe something.

Based on the explanation above, the researcher was interested to introduce Concept Circle Strategy to teach vocabulary in the school. The researcher wants to know whether Concept Circle Strategy give significant effect on students' vocabulary mastery or not. So, this strategy can be used for the next time by researcher herself or other teachers if it gives positive effect for students. This reason finally guides the researcher to formulate the title "The Effect of Concept Circle Strategy on Students' Vocabulary Mastery at Grade VII MTs $N 2$ Padangsidimpuan".

\section{B. Purposes of the Research}

1. To describe the students' vocabulary mastery before using concept circle strategy at grade VII MTsN 2 Padangsidimpuan.

2. To describe the students' vocabulary mastery after usingconcept circle strategy at grade VII MTsN 2 Padangsidimpuan.

3. To know there is a significant effect concept circle to students' vocabulary at grade VII of MTsN 2 Padangsidimpuan or not.

\footnotetext{
${ }^{1}$ English Teacherin MTs N 2 Padangsidimpuan, Private Interview. Tuesday, 05 October 2016.
} 


\section{The Theoretical Description}

\section{Vocabulary Mastery}

Vocabulary is one aspect which own by every student to make them understand and master english language. It is a part of language that so important to all aspect in life. Hornby said " vocabulary is all the words that person know or use, the words that people use when they are telling about particular subject". ${ }^{2}$ Then, Jack C. Richard and Willy A Renandya said "Vocabulary is a core component of language proficiency and provides much of the basic for how well learners speak, read, listen and write". ${ }^{3}$ It means words can be noun, verb, adverbs, adjectives, preposition, and conjuction to use language. Then language is some words or vocabulary for speak, listen, read and write. According to Ur Penny "vocabulary is the words we teach in foreign language". It is mean vocabulary is the list of words that work in language and it is teach by the teacher based on the student's level. Then, according to Jackson, vocabulary is a representative collection of the words that exist in the English language. ${ }^{5}$ So, vocabulary is the words that are known and use by human. Vocabulary is so important for the students because it is the core part of the language and has the link to each skill in English.

It can be concluded that vocabulary is list of words that are understood and used to communicate in a language.Then, vocabulary is the words that are known and used by human. Vocabulary is so important for the students because it is the core part of the language and has the link to each skill in English.

Vocabulary mastery is especially important in reading. The Report of the National Reading Panel, for example, concluded "The importance of vocabulary knowledge has long been recognized in the development of reading skills. As early as 1924, researchers noted that growth in reading power relies on continuous growth in word knowledge" as quoted by John and Shane. ${ }^{6}$

\footnotetext{
${ }^{2}$ A. S. Hornby, Oxford Advanced Learner's Dictionary, (New York: Oxford University Press, 1995 ) p. 1506.

${ }^{3}$ Jack C. Richard and Willy A. Renandya, Methodology in Language Teaching and Anthology of Current Practice, (USA: Cambridge University Press, 2000), p. 255.

${ }^{4}$ Penny Ur, A Course in Language Teaching (United Kingdom: University Press, 2000), p. 60.

${ }^{5}$ Howard Jackson, Words, Meaning and Vocabulary (London: Casell, 2000), p. 118.

${ }^{6}$ John J. Pikulski and Shane Templeton, Teaching and Developing Vocabulary: Key to LongTerm Reading Success, (USA: Houghton Mifflin Company, 2004), p. 1.
} 
Furthermore, McKeown states that there is a strong relationship between vocabulary knowledge and reading. He explains it as follow:

Without adequate vocabulary knowledge, students cannot fully understand what they read, and they will have difficulty with content instruction. Students with good vocabulary knowledge will comprehend text more easily, which leads them to more extensive reading and, in turn, greater vocabulary growth. Vocabulary development is a critically important aspect of instruction for all students and especially for English learners. Keep in mind that vocabulary is best learned within the context of interesting activities, not by memorizing lists of words or copying definitions. ${ }^{7}$

This quotation shows that vocabulary enables learners to understand the text easily. Bishop and colleagues also state that a reader must have rich vocabulary to support understanding of text. The reader need to understand the words the author has chosen to use. The less learners understand words, the less they are able to comprehend the passage. ${ }^{8}$ From previous explanations it can be concluded that vocabulary can't be separated from learners' reading activities.

\section{c. The Material of Teaching Vocabulary at MTs N 2 Padangsidimpuan}

There are many materials in vocabulary teaching. As has been explained above, there are some kinds of vocabulary, such as receptive vocabulary and productive vocabulary. So, the English learner can learn or understand vocabulary while listening to a spoken English or reading a passage and produce it when do speaking or writing activities. So, it is relevant with English lesson syllabus of Indonesian curriculum that places these four activities within it. The book used in MTs N 2 Padangsidimpuan iswhen English rings the bell. It divided into eight units, they are : family ( unit I ), names of the days, months and years (unit II), favorite or hobbies (unit III), things in the classroom, things in my kicthen, parts of the house, animals in my school and my home (unit IV), profession ( unit V), animals and things (unit

\footnotetext{
${ }^{7}$ Carmen Zuñiga Dunlap and Evelyn Marino Weisman, Helping English Language Learners Succeed: Practical Strategies for Successful Classrooms, (U.S.A: Shell Education 2006), p. 145.

${ }^{8}$ Ashley Bishopet. al., Vocabulary Instruction for Academic Purpose, (USA: Shell Education, 2009), p. 13.
} 
VI), people (unit VII), and warning/cautions (unit VIII). ${ }^{9}$ There are some examples of material vocabulary in MTs N 2 Padangsidimpuan:

\section{Talking about Things in my kicthen}

A. Please, match the appropriate words based on the pictures!

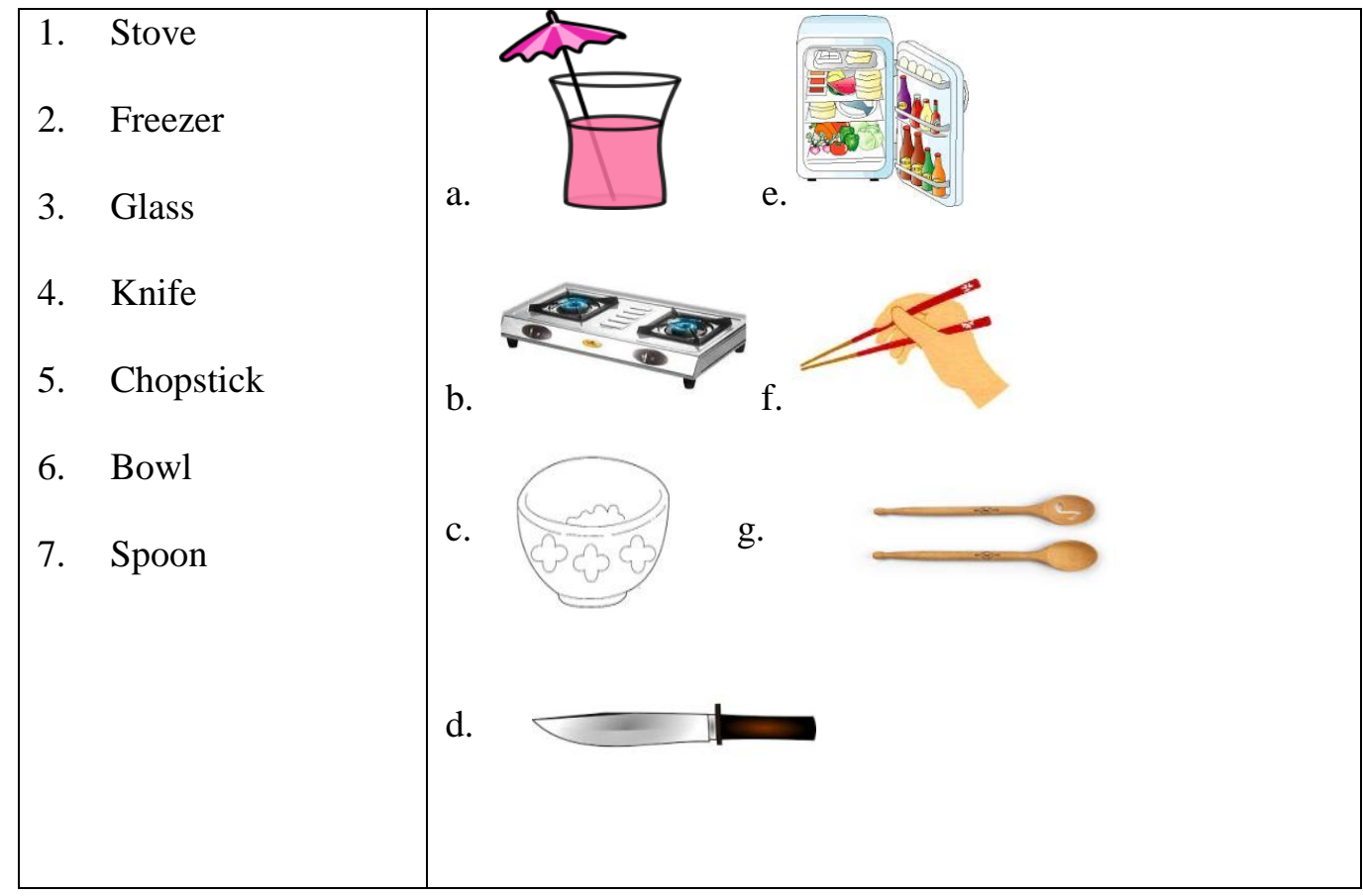

Source: Mukarto,et. al., English on Sky for Junior High School Students Year VII,PenerbitErlangga, 2007.

Talking about profession

$B$. Choose the appropriate word above to complete the sentence !

$\begin{array}{ll}\text { a. } & \text { Chef } \\ \text { b. } & \text { football player } \\ \text { c. } & \text { photographer } \\ \text { d. } & \text { teacher } \\ \text { e. } & \text { barber } \\ \text { f. } & \text { singer } \\ \text { g. } & \text { doctor } \\ \text { h. } & \text { fisherman } \\ \text { i. } & \text { pianist } \\ \text { j. } & \text { dentist }\end{array}$

1. Christian Ronaldo is my favorite

2. Ayu is the famous in her town. She can play piano very well.

3. My brother is a people to treat their illness.

4. I see a He always helps big fish.

5. I always check my teeth condition to the regularly.

6. Justin bieber is my favourite

7. I do not like the vey shortly.

8. Sam is a professional She cut my hair He can takes

${ }^{9}$ Bahasa Inggris, When English Rings the Bell for junior high school students years VII . Kementrian Pendidikan dan Kebudayaan, Jakarta: Kementrian Pendidikan dan Kebudayaan, 2013. 


\begin{tabular}{|l|l|}
\hline 9. $\begin{array}{l}\text { beautiful photo. } \\
\text { Myster works in the restaurant. She is a } \\
\text { 10. Our She can makes delicious food. } \\
\text { mathematic to us. }\end{array}$ \\
\hline
\end{tabular}

Source: Mukarto,et. al., English on Sky for Junior High School Students Year VII,PenerbitErlangga, 2007.

\section{Concept Circle}

\section{a. Definition of Concept Circle}

According to Mark Twain Concept Circles is a visual organizer, similar to Frayer Model, which helps students understand key words and concepts. A Concept Circles is divided into four or more equal sections to hold words or symbol that are connected by a common relationship. ${ }^{10}$ Concept circles strategy is a suitable strategy to increase the students' vocabulary achivement in reading descriptive text. It is an activity that can be use across a wide range of grade levels. It is help students analyze connections between words and to explain relationships among words and topic. ${ }^{11}$ According to J. Allen concept circle is teaching about vocabulary with use circle. Circle which form game because circle devide four or more sections, with word or phrase in each section of the circle. In the circle students can be fill in the blank with follow the topic, or characteristic as a clues. $^{12}$

It is mean concept circle is not only use to increase students' vocabulary but also motivate to learning vocabulary. Vocabulary circle is a fun activity to students'. Concept circles are an activity that can be used across a wide range og grade levels. The goal of the activity is for students to relate words conceptually to each other. Students are given a circle divided into parts with words or phrases written into each section. Teacher

\footnotetext{
${ }^{10}$ Mark, Twain.1890. Teaching Vocabulary: Vocabulary Skill can make or break any Students feelings about reading, p. 46. Accessed on October, $25^{\text {th }} 2016$ at $08.00 \mathrm{pm}$. From ( http:// www. Storage/emulated/0/Vocabulary_Strategy.Pdf ).

${ }^{11}$ Kimberly, Kimbell-Lopez.2009, Teaching Vocabulary Material and Methods for Teaching Reading,p. 19 from http://hlperson.com/mt/archives/vocabulary.gif.

${ }^{12}$ Allen, Janet, Word, Word, Word, Teaching Vocabulary in Grades 4-12 (Portlandmaine: Sthenhouse, 1999), p. 101.
} 
give the intriruction or clues in circle. So, make a students easy to answer and understand about learning vocabulary.

It can be concluded that Concept Circles help focus to enrich students vocabulary. Where are students can be used this strategy to describe things. Then, make students interested to learned.

\section{d. Advantages and Disadvantages of Concept Circle Strategy}

Concept circle is an organizer which is divided into sections to hold word/symbols that are connected by a common relationship. There are some advantages of using Concept circle strategy in teaching English, they are:

1) Help student understand the meaning of words.

2) Provide students with the opportunity to think about a word in multiple ways.

3) To help focus students discussion and help students to enrich the vocabulary. ${ }^{13}$

Besides that, by using concept circle in the classroom, students will get more payoffs, as following description. The students will be able to:

1) Develop understanding of key concepts and vocabulary.

2) Draw on prior knowledge to make connections among concepts.

3) Compare attributes and examples.

4) Think critically to find relationships between concepts and to develop deeper understanding. ${ }^{14}$

Then, there are some disadvantes of using concept circle strategy in teaching English, there are:

1) The teacher difficulties to find the words which appropriate with students competence.

2) It cannot use for every learning. ${ }^{15}$

The points above also show that there are some advantages when a teachers use concept circle in their teaching activities. It gives teacher the strong reason to use this strategy to teach vocabulary. So, concept circle is a strategy that is computable to be used in English classroom.

\footnotetext{
${ }^{13}$ Think works: Vocabulary Stratey, Teaching Comprehension, retrieved from http://oame.on.ca/main/files/thinklit/conceptcircle.pdf onjanuary20 $0^{\text {th }}, 2017$ at 10.15 p.m. .

${ }^{14}$ Think Literacy: Mathematics Subject-Specific Examples Grades 7-9retrieved from http://oame.on.ca/main/files/thinklit/conceptcircle.pdfon September20 th 2016, at 10.15p.m., p. 34 .

${ }^{15}$ Ibid., p. 35.
} 


\section{Research Design}

The kind of this research is quantitative method with experimental method. Experimental method is a research with a purpose to find the effect of one or more variables to the other variable. It is a research that can test hypothesis based on cause and effect relationship between one variable to the other variable.

Creswell state " experimental research include the experiment with the random assignment of the subject to treatment condition as well as quasi experiment that use none randomized". 16

From the definition above, the researcher conclude that the experimental is kind of research that is aim to know the causal effect relationship between one or more variable to other variables.

In this research, the researcher use two class, as an experimental class and control class. The experiment class is the class that teach with cocept circle strategy, as a treatment. Then, the control class is the class that teach with use conventional strategy or without treatment. The research design of this research can be see from the table:

Table 1. Pretest-Posttest Control Group Design

\begin{tabular}{|c|c|c|c|}
\hline Class & Pre-test & Treatment & Post-test \\
\hline Experimental class & $\sqrt{ }$ & Concept Circle Strategy & $\sqrt{ }$ \\
\hline Control class & $\sqrt{ }$ & Conventional Strategy & $\sqrt{ }$ \\
\hline
\end{tabular}

From the definition above, researcher concludes that the experimental research was a kind of research that tries to observe the cause and effect relation between one variable with another variable. Variables in this research are concept circle and student's vocabulary mastery. Experimental research also used to know the cause and effect relations by comparing the result of experimental group who get a treatment with control group who do not get a treatment. Experimental class is the class that taught with concept circle as a treatment. Meanwhile the control class is a class that taught with using conventional strategy or without a treatment.

\section{E. Instrument of Collecting Data}

\footnotetext{
${ }^{16}$ Jhon Creswell. Research Design Qualitative, Quantitative and Mixed Methods Approaches Second Edition, (USA: Prentice Hall, 2000), p. 14.
} 
Instrument is a tool that can be use by the researcher to collect the valid and reliable data. In this research, the researcher will use a test. Good instrument certify the validity of the data. The reseacrcher use instrument of validity and reliability for the take the valid data. The researcher use test as instrumentation. Test is some of question or view or other tool use for measure skill, knowledge, intelligence and ability.

The researcher collect by give the multiple-choice test. In this research, before validity the test consist of 100 questions, where 50 for pre-test, and 50 for post-test. This give to both group, expeiment and control class.

Table 2. The indicator of vocabulary Pre-Test

\begin{tabular}{|c|c|c|c|c|c|c|}
\hline No & Indicator & Topic & Number of Items & Item & $\begin{array}{l}\text { core } \\
\text { Per } \\
\text { Item }\end{array}$ & $\begin{array}{l}\text { Total } \\
\text { Score }\end{array}$ \\
\hline \multirow[t]{2}{*}{1} & \multirow{2}{*}{$\begin{array}{l}\text { Identifying } \\
\text { the definition } \\
\text { of words }\end{array}$} & $\begin{array}{l}\text { Profession/jo } \\
\text { b }\end{array}$ & $1,2,3,4,5,6,7,8$ & 8 & \multirow{8}{*}{2} & 16 \\
\hline & & $\begin{array}{l}\text { Things in } \\
\text { my kicthen }\end{array}$ & $9,10,11,12,13,14,15$ & 7 & & 14 \\
\hline \multirow{2}{*}{2} & \multirow{2}{*}{$\begin{array}{l}\text { Identifying } \\
\text { the word } \\
\text { association } \\
\text { of words }\end{array}$} & $\begin{array}{l}\text { Thigs in my } \\
\text { kicthen }\end{array}$ & $16,17,18,19,20,21,22$ & 7 & & 14 \\
\hline & & $\begin{array}{l}\text { Job:work } \\
\text { place }\end{array}$ & $\begin{array}{c}23,24,25,26,27,28, \\
29\end{array}$ & 7 & & 14 \\
\hline \multirow{4}{*}{3} & \multirow{4}{*}{$\begin{array}{l}\text { To memories } \\
\text { the words }\end{array}$} & $\begin{array}{l}\text { Profession } \\
\text { /job }\end{array}$ & $30,31,32,33,34,35,36$ & 7 & & 14 \\
\hline & & \multirow{2}{*}{$\begin{array}{l}\text { Job: work } \\
\text { place }\end{array}$} & \multirow{2}{*}{$37,38,39,40,41,42,43$} & \multirow{2}{*}{7} & & 14 \\
\hline & & & & & & 14 \\
\hline & & $\begin{array}{l}\text { Things in } \\
\text { my kicthen }\end{array}$ & $44,45,46,47,48,49,50$ & 7 & & 14 \\
\hline & \multicolumn{3}{|c|}{ Total } & 50 & & 100 \\
\hline
\end{tabular}

Table 3. The indicators of vocabulary Post-test

\begin{tabular}{|c|c|c|c|c|c|c|}
\hline No & Indicator & Topic & $\begin{array}{l}\text { Number of } \\
\text { Items }\end{array}$ & Item & $\begin{array}{l}\text { Score Per } \\
\text { Item }\end{array}$ & $\begin{array}{l}\text { Total } \\
\text { Score }\end{array}$ \\
\hline \multirow{2}{*}{1} & \multirow{2}{*}{$\begin{array}{l}\text { Identifying } \\
\text { the definition } \\
\text { of words }\end{array}$} & $\begin{array}{l}\text { Things in my } \\
\text { kicthen }\end{array}$ & $\begin{array}{c}1,2,3,4,5,6 \\
7,8\end{array}$ & 8 & \multirow[t]{3}{*}{ Nen } & 1 \\
\hline & & $\begin{array}{l}\text { Profession/jo } \\
\text { b }\end{array}$ & $\begin{array}{c}9,10,11,12,13 \\
14,15\end{array}$ & 7 & & 1 \\
\hline & & $\begin{array}{l}\text { Job:work } \\
\text { place }\end{array}$ & $\begin{array}{l}16,17,18,19,20 \\
.21,22\end{array}$ & 7 & & $4^{1}$ \\
\hline
\end{tabular}


VOL. 5 NO. 1. JANUARY 2017

\begin{tabular}{|c|c|c|c|c|c|}
\hline \multirow[b]{2}{*}{2} & \multirow{2}{*}{$\begin{array}{l}\text { Identifying } \\
\text { the word } \\
\text { association } \\
\text { of words }\end{array}$} & $\begin{array}{l}\text { Thigs in my } \\
\text { kicthen }\end{array}$ & $\begin{array}{l}23,24,25,26,27 \\
, 28,29 \\
\end{array}$ & 7 & 4 \\
\hline & & $\begin{array}{l}\text { Job:work } \\
\text { place }\end{array}$ & $\begin{array}{c}30,31,32,33,34 \\
, 35,36\end{array}$ & 7 & $4^{1}$ \\
\hline \multirow{2}{*}{3} & \multirow{2}{*}{$\begin{array}{l}\text { To memories } \\
\text { the words }\end{array}$} & $\begin{array}{l}\text { Profession } \\
\text { /job }\end{array}$ & $\begin{array}{c}37,38,39,40,41 \\
, 42,43\end{array}$ & 7 & $4^{1}$ \\
\hline & & $\begin{array}{l}\text { Things in my } \\
\text { kicthen }\end{array}$ & $\begin{array}{c}44,45,46,47,48 \\
, 49,50 \\
\end{array}$ & 7 & $4^{1}$ \\
\hline & \multicolumn{3}{|c|}{ Total } & 50 & 100 \\
\hline
\end{tabular}

\section{F. Conclusion}

Based on the result of the research, the conclusions of this research is there was a significant effect concept circle strategy on students' vocabulary mastery at grade VII MTs N 2 Padangsidimpuan. The researcher found the result of t-test where $t_{0}$ was higher than $t_{t}$. $t_{0}$ was 4.205 and $t_{t}$ was $2.021(4.205>2.021)$. It means that where $\mathrm{H}_{\mathrm{a}}$ was accepted and $\mathrm{H}_{0}$ was rejected. Before using concept circle strategy the mean score of experimental class was 55.62 and the mean score of control class which was taught by conventional strategy was 53.22. After using concept circle strategy the mean score of experimental class was 82.62and the mean score of control class which was taught by conventional strategy was 68.58 . 


\section{REFERENCES}

Agus Irianto. Statistik Konsep Dasar dan Aplikasinya. Padang: P2LPTK Departemen Pendidikan Nasional. 2003.

Annur, Latifah. "The Effect of Verbal and Visual Word Association Strategy towardVocabulary Mastery at Grade VIII Students of SMPN 1 Panyabungan Selatan 2015/2016 Academic Year" Unpulished Thesis: IAIN Padangsidimpuan 2016.

Allen, Janet, Word, Word, Word, Teaching Vocabulary in Grades 4-12, Portland maine: Sthenhouse, 1999.

Arikunto, Suharsimi, Prosedur Penelitian Suatu Pendekatan Praktik, Jakarta: Rineka Cipta, 2006.

Bishop, Ashley,et. al., Vocabulary Instruction for Academic Purpose, USA: Shell Education, 2009.

Creswell, John W., Research Design: Qualitative, Quantitative and Mixed Method Approaches $2^{\text {nd }}$ Edition, California; Sage Publication, 2003.

Deriden, Jhon."Conventional Strategy" retrieved from: http://www.Britania.com/ Ebchecked/topicIc/421797/nnuclear-strategy/52993/conventional-strategyon May $7^{\text {th }} 2017$ at 10.00 p.m.

Dunlap, Carmen Zuñigaand Evelyn Marino Weisman, Helping English Language Learners Succeed: Practical Strategies for Successful Classrooms, U.S.A: Shell Education 2006.

Gay, L. R., \& Peter Airasian, Educational Research: Competent for Analysis and Application, New Jersey: Prentice Hall, 2000.

Gattegno, Caleb. Teaching Foreign Language in Schools, New York: Educational Solution, 1972.

Harmer, Jeremy, The Practical of English Language Teaching, New York: Longman, 2000.

Hiebert, Elfrieda H. and Michael L. Kamil, Teaching and Learning Vocabulary:Bringing Research To Practice. New Jersey: Lawrence Erlbaum Associates, Publishers, 2005.

Hornby, A.S. Oxford Advanced Learner's Dictionary, New York: Oxford University Press, 1995. 
Hudson, The Meaning of Conventional Strategy, retrieved from: http://www.conventional-strategy/topic/54372-strategyon October $7^{\text {th }} 2016$ at 10.00 p.m.

Inbaraj, J.,English Language Teaching, Chennai, India: Tamilnadu Textbook Corporation 2008.

Johnston, Deirdre D, Scott W. Vanderstoep, Research Methods for Everyday Life: Blending Qualitative and Quantitative Approaches, San Fransisco: Jossey Bass, 2009.

Jackson, Howard and Etienne Ze Amvela ,Words, Meaning, and Vocabulary: An Introduction to Modern Lexicology,London: Cassel, 2000.

Kasbolah, Kasihani. Teaching Learning Strategy, Malang: IKIP Malang, 1993.

Lopez-Kimbell, Kimberly. Teaching Vocabulary Material and Methods for Teaching Reading, 2009 from http://hlperson.com/mt/archives/vocabulary.gif.

Meltzer, Julie and Edmund T. Hamann, Meeting the Literacy Development Needs of Adolescent English Language Learners Through Content Area Learning: Focus on Classroom Teaching and Learning Strategies, The Education Allianceat Brown University, 2005.

Mukarto,et. al., English on Sky for Junior High School Students Year VIII, Penerbit Erlangga, 2007.

Nunan, David. Practical English Language Teaching, New York:Mc.Grow Hill, 2003.

Nelson, Thomas. The Award Compact English Dictionary, London: Award Publication, 1985.

Pikulski, John J. and Shane Templeton, Teaching and Developing Vocabulary: Key to Long-Term Reading Success, USA: Houghton Mifflin Company, 2004.

Prime, Andrean. Steps Implementing Teaching Method,Avaiable at http://materiinside/2014/12 /langkah- zmelaksanakan -metode-ceramah.html, Accessed on January, 20, 2017 at $11.00 \mathrm{am}$.

Richard, Jack C. and Richard Schmidt, Longman Dictionary of Language Teaching and Applied Linguistics, Third Edition, Harlow: Pearson Education, 2002.

Setiawan, DodikHeru. Defenition, Adventages and Disadventages Lecture Method, Avaiable at http://zonainfosemua./2011/01/pengertian-kelebihan-dankekurangan.html. Accessed on, January, 20, 2017 at 10.15 a.m.

Sudijono, Anas, Pengantar Statistik Pendidikan Jakarta: Raja Grafindo Persada, 2005.

Pengantar Evaluasi Pendidikan, Jakarta: PT. Raja Grafindo Persada, 1996. 
Sugiyono, Metode Penelitian Kuantitatif, Kualitatif, dan $R \& D$, Bandung: Alfabeta, 2013.

Susan, Hanson and Jennifer F.M. Padua. Teaching Vocabulary Explicitly, U.S.: Institute of Education Sciences, 2011.

Think works: Vocabulary Stratey, Teaching Comprehension, retrieved from http://oame.on.ca/main/files/thinklit/conceptcircle.pdf on january $20^{\text {th }}, 2017$ at 10.15 p.m.

Think Literacy: Mathematics Subject-Specific Examples Grades 7-9 retrieved from http://oame.on.ca/main/files/thinklit/conceptcircle.pdf on September $20^{\text {th }} 2016$, at 10.15p.m.

Ur, Penny. A Course in Language Teaching, United Kingdom: University Press, 2000. 